\title{
DECREASE IN THE PITUITARY RESPONSE TO SYNTHETIC LH-RF IN CASTRATED RAMS FOLLOWING TESTOSTERONE PROPIONATE TREATMENT
}

\author{
J. PELLETIER \\ I.N.R.A., Station de Physiologie de la Reproduction, \\ 37380 Nouzilly, France
}

(Received 17th April 1974)

\begin{abstract}
Summary. The pattern of plasma LH levels in castrated rams after injection of testosterone propionate (TP) was biphasic with significant decreases at 12 and $72 \mathrm{hr}$ after injection. The total $\mathrm{LH}$ response of similarly treated rams injected with LH-RF at critical times in the biphasic LH pattern was of three types regardless of the dose of LH-RF : (i) a similar response to that of control animals at 12,72 and $120 \mathrm{hr}$ after TP, (ii) a greater response than that of control animals at $36 \mathrm{hr}$ after TP (this is regarded as a rebound effect after a partial inhibition of the release), and (iii) a lower response than that of control animals $6 \mathrm{hr}$ after TP. The third type of response suggests that in the ram testosterone may act directly at the pituitary level to decrease the responsiveness to LH-RF.
\end{abstract}

\section{INTRODUCTION}

Pelletier \& Ortavant (1972) reported that testosterone propionate (TP) induced a biphasic decrease in the plasma LH of castrated rams 12 and $72 \mathrm{hr}$ after intramuscular injection. These two phases were separated by a return of plasma LH to the preinjection level. Since it was shown that the second decrease, could be due to a blockage of the synthesis of LH-RF at the hypothalamic level (Pelletier, 1970), the present studies were undertaken to determine which mechanisms control the first inhibition phase. As it has been suggested that steroids could modify the sensitivity of the pituitary to LH-RF (Reeves, Arimura \& Schally, 197la), this hypothesis was tested by comparing the effectiveness of synthetic LH-RF on the release of LH in castrated rams when given at different times relative to a single androgen injection.

An initial experiment was needed to verify that the biphasic pattern of plasma LH after steroid treatment was similar in March, when this study was carried out, to the pattern obtained in December (Pelletier \& Ortavant, 1972), since we have evidence of seasonal variations of $\mathrm{LH}$ response to steroid injection. 


\section{MATERIALS AND METHODS}

Experiment 1 was carried out in March 1972, and seven Préalp rams, castrated 3 months before, were used. Each animal received $600 \mathrm{mg}$ TP, dissolved in 8 $\mathrm{ml}$ olive oil, injected intramuscularly at two sites in the neck. Jugular blood samples were collected by venepuncture every $2 \mathrm{hr}$ (starting just before the steroid injection) for $36 \mathrm{hr}$ and then every $12 \mathrm{hr}$ for a further $84 \mathrm{hr}$.

Experiment 2 was carried out in February to April 1973, and twenty-seven Préalp rams, castrated 6 to 9 months before, were used.

The controls consisted of four rams which received intravenous injections of $2 \mathrm{ml}$ saline and a further ten rams which received either $25 \mu \mathrm{g}$ (four animals) or $100 \mu \mathrm{g}$ (six animals) of synthetic LH-RF (Cyclochemical).

Twenty-three rams received an injection of $\mathrm{TP}$ as in the first experiment followed by intravenous injection of LH-RF ( 25 or $100 \mu \mathrm{g}$ ) at 6, 12, 24, 72 or $120 \mathrm{hr}$ after the androgenic treatment (two to four animals per group). These intervals were chosen to correspond with critical times in the biphasic pattern of plasma LH observed in the first experiment. Blood samples were collected every $15 \mathrm{~min}$ from the jugular veins of all animals over a period of $5 \mathrm{hr}$. Just before the injection of LH-RF, five more samples were collected every $5 \mathrm{~min}$ from the treated rams.

Plasma samples were stored at $-12^{\circ} \mathrm{C}$ until they were subjected to radioimmunoassay for LH as described previously (Pelletier, Kann, Dolais \& Rosselin, 1968). Basal LH levels were taken as the mean of the five pretreatment samples. The total response was defined as the area under the curve of LH concentration plotted against time and bounded by the line of the basal level. It was proportional to the weight of paper graphically representing this area and was expressed in $\mathrm{ng} / \mathrm{ml} / \mathrm{hr}$.

\section{RESULTS}

\section{Pattern of $L H$ release after testosterone propionate}

The injection of $600 \mathrm{mg}$ TP in castrated rams was followed by a highly significant decrease in plasma LH $(P<0.01)$ which was maximal 10 to $12 \mathrm{hr}$ later (Text-fig. 1). The plasma LH level then increased with oscillations to the preinjection level where it stayed for $12 \mathrm{hr}$ (from $24 \mathrm{hr}$ to $36 \mathrm{hr}$ after TP). A second decrease took place later and the minimum level was reached at $72 \mathrm{hr}$. Again, it was significantly less $(P<0.02)$ than the preinjection level. At $96 \mathrm{hr}$, the level had risen to be more than that of the level at the outset.

\section{Response of $L H$ to $L H-R F$}

Controls. The pattern of $\mathrm{LH}$ release in representative individuals from the two control groups are shown in Text-fig. 2. In control rams receiving no treatment, only minor fluctuations in plasma LH were evident. In contrast to these, the control rams treated with LH-RF exhibited a marked increase in plasma LH. The LH release was higher in rams which received $100 \mu \mathrm{g}$ LH-RF than in those which received $25 \mu \mathrm{g}$. In both cases the maximum $\mathrm{LH}$ value was reached $15 \mathrm{~min}$ after injection and this also represented the mean for all individuals. 


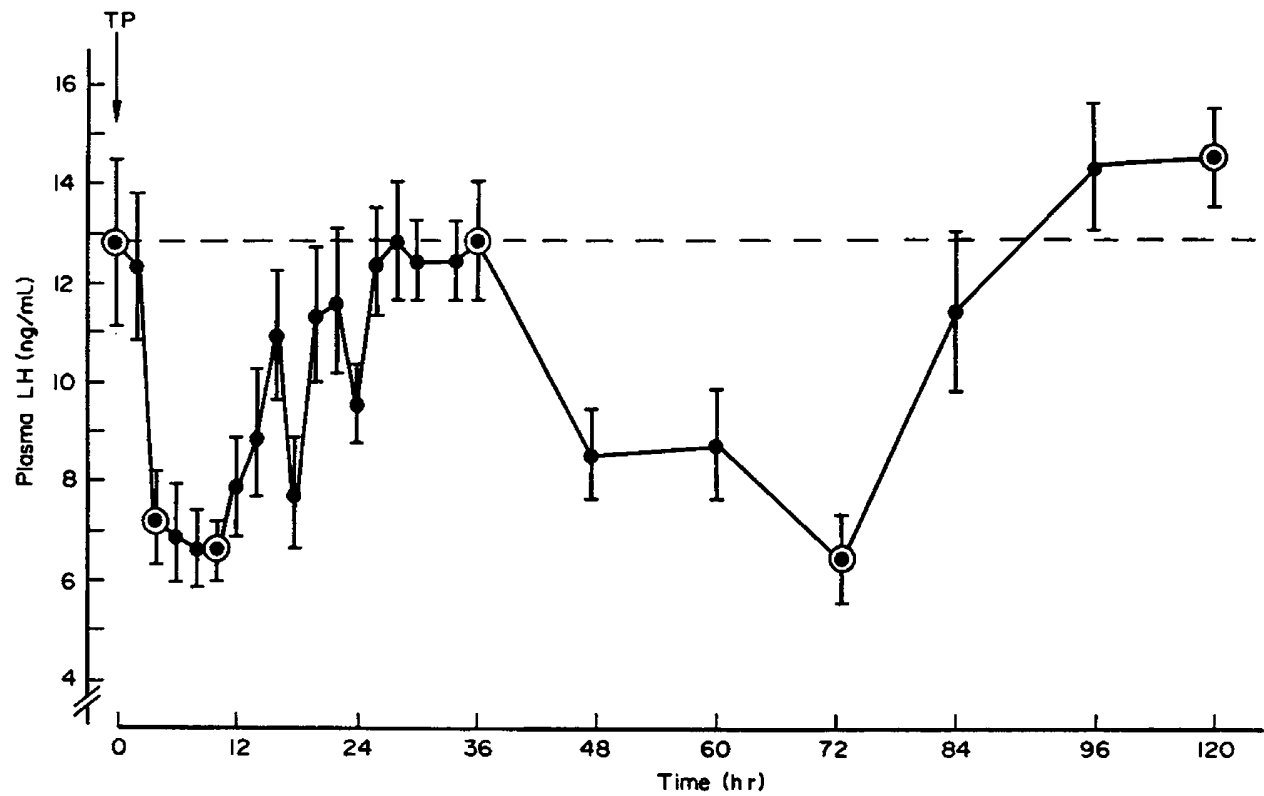

TExT-Fic. 1. Plasma LH levels in seven rams, castrated 3 months previously, following an injection of $600 \mathrm{mg}$ testosterone propionate (TP) $\odot$, Plasma $\mathrm{LH}$ level at the times chosen in Exp. 2 for the injection of LH-RF. Vertical bars represent the S.E.M.

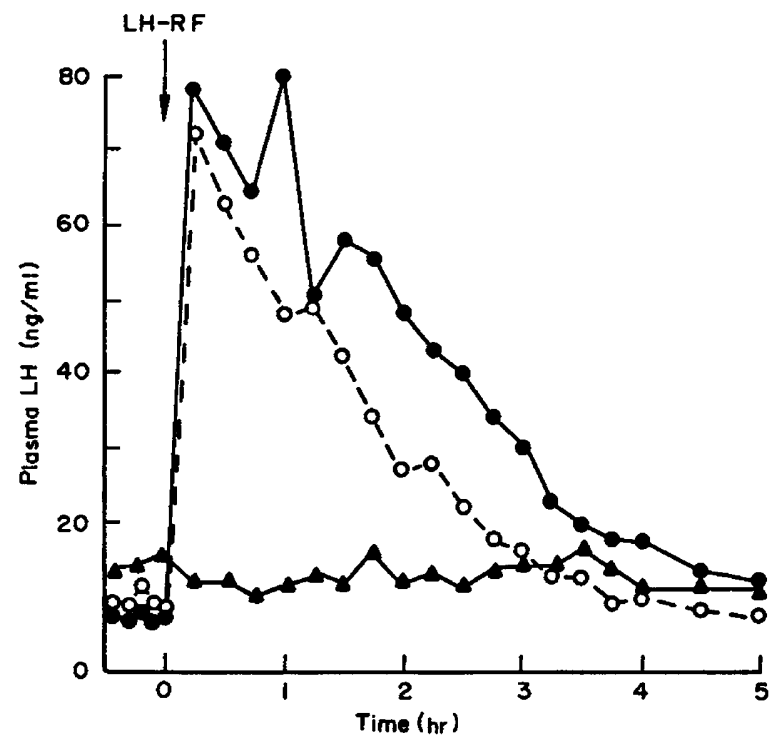

TexT-Fig. 2. Plasma LH variations in representative castrated control rams which received $0(\Delta), 25 \mu \mathrm{g}(0)$ or $100 \mu \mathrm{g}(\bullet)$ synthetic LH-RF but were not treated with testosterone propionate. 
Table 1. Total LH release after intravenous administration of synthetic LH-RF to castrated rams pretreated at different times after injection with testosterone propionate

\begin{tabular}{c|cccccc}
\hline $\begin{array}{c}\text { Dose of } \\
L H-R F \\
(\mu g)\end{array}$ & $0($ Controls $)$ & 6 & 12 & 36 & 72 & 120 \\
\hline 100 & $150 \cdot 3 \pm 2 \cdot 95$ & $96 \cdot 0 \pm 5 \cdot 46$ & $126 \cdot 2 \pm 11 \cdot 69$ & $201 \cdot 9 \pm 32 \cdot 2$ & $132 \cdot 0 \pm 6 \cdot 33$ & $153 \cdot 7$ \\
& $(6) \dagger$ & $(4)$ & $(3)$ & $(3)$ & $(3)$ & $(2)$ \\
25 & $81 \cdot 3 \pm 7 \cdot 12$ & $55 \cdot 0$ & $114 \cdot 9$ & $239 \cdot 0$ & - & $116 \cdot 7$ \\
& $(4)$ & $(2)$ & $(2)$ & $(2)$ & & $(2)$ \\
& & $(4)$ & & & & \\
\end{tabular}

The total $\mathrm{LH}$ release values, expressed in $\mathrm{ng} / \mathrm{ml} / \mathrm{hr}$, were calculated by weighing the paper graphically representing the area under the curve of LH concentration plotted against time and bounded by the basal preinjection level assumed to be constant.

* $600 \mathrm{mg}$ TP in $8 \mathrm{ml}$ olive oil administered in two intramuscular sites in rams castrated 6 to 9 months previously.

$\dagger$ Number of animals/group. Each ram was used in only one treatment group. Some of them acted as controls, and then as experimental animals 3 weeks later.

The return to the preinjection level took place at a mean of $5 \mathrm{hr}$ later for the rams receiving $100 \mu \mathrm{g}$ and $3 \frac{3}{4} \mathrm{hr}$ later for the rams receiving $25 \mu \mathrm{g}$. The $\mathrm{LH}$ pattern of the control ram treated with $100 \mu \mathrm{g}$ was typical of that frequently observed, i.e. with two peaks of the same magnitude separated by 45 to $60 \mathrm{~min}$.

Experimental. The total LH response of the pituitary to LH-RF given at different times after TP are shown in Table 1. Three types of release of $\mathbf{L H}$ were observed when rams were pretreated with TP: (i) the total LH release was similar to that observed in controls treated with LH-RF at $12 \mathrm{hr}, 72 \mathrm{hr}$ and $120 \mathrm{hr}$ after TP. The peak of LH was lower, however, than that of the

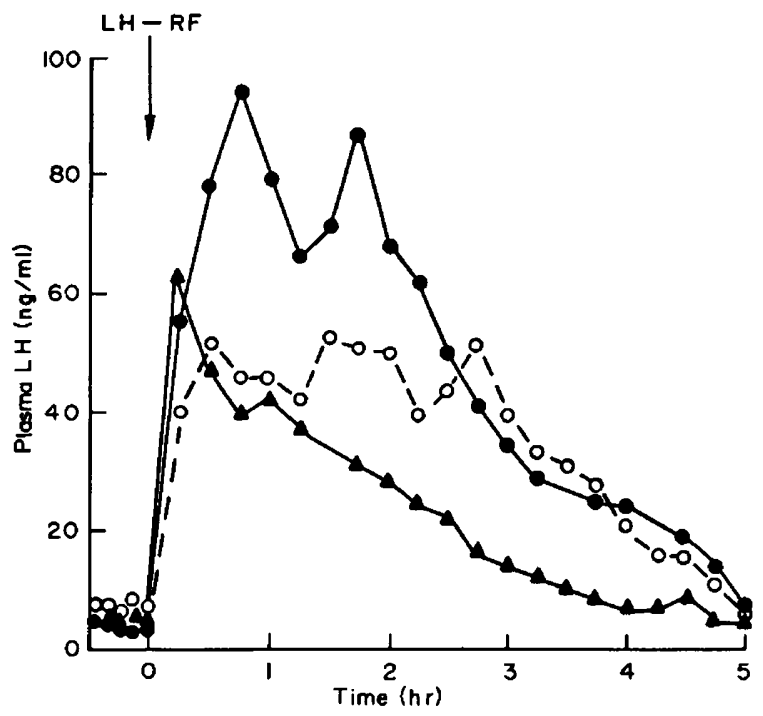

TEXr-FIG. 3. The effect of $100 \mu \mathrm{g}$ LH-RF on LH release in three representative castrated rams which were pretreated with $600 \mathrm{mg}$ testosterone propionate $6 \mathrm{hr}(\Delta), 12 \mathrm{hr}(0)$ or $36 \mathrm{hr}(\bullet)$ previously. 
controls in rams which received LH-RF 12 or $72 \mathrm{hr}$ after the TP injection. This maximum value was maintained for 2 to $3 \mathrm{hr}$ (Text-fig. 3); (ii) the total LH release was lower than that of the controls in rams which received LH-RF $6 \mathrm{hr}$ after TP. The difference was highly significant $(P<0 \cdot 001)$ in those animals which were treated with $100 \mu \mathrm{g}$ LH-RF. The LH peaks occurred at almost the same time as those of the controls, regardless of the dose of LH-RF. The pattern of LH release was similar, but on a smaller scale, to that of the controls (Text-figs 1 and 3); (iii) the total LH release was greater than that of the controls at $36 \mathrm{hr}$ after TP (Text-fig. 3). In animals treated with $25 \mu \mathrm{g} \mathrm{LH}-\mathrm{RF}$, the difference was about $300 \%$.

\section{DISCUSSION}

The results of the first experiment carried out in March were similar to those obtained previously in December (Pelletier \& Ortavant, 1972) in that the two decreases in plasma LH concentration after the injection of TP took place at the same times in both experiments, i.e. at $12 \mathrm{hr}$ and $72 \mathrm{hr}$. It was therefore possible to test the effect of LH-RF on LH release into the blood at critical times of the biphasic $\mathbf{L H}$ release pattern observed after treatment with TP.

The large quantity of $\mathrm{LH}$ released into the blood in castrated rams which only received injections of LH-RF (see the present results and those of Reeves et al., 1970) nullified any possible disturbances due to circhoral variations which were first suggested in ovariectomized monkeys (Dierschke, Bhattacharya, Atkinson \& Knobil, 1970) and also in rams (Bolt, 1971; Butler, Malven, Willett \& Bolt, 1972). The peak of LH release after LH-RF in castrated rams is considerably higher than that observed in intact rams (Reeves et al., 1970, 1971b). There are frequently two maxima of the same amplitude as if freshly synthesized LH reinforces the LH release at the time of the second peak. The biphasic pattern is clearly demonstrated in Text-figs 2 and 3.

The total response to LH-RF was quantitatively modified when it was given at precise times after the injection of TP, i.e. at $6 \mathrm{hr}$ and $36 \mathrm{hr}$. Conversely, no changes in the total response to LH-RF could be detected at other times even though the plasma LH levels were significantly lower at $12 \mathrm{hr}$ and $72 \mathrm{hr}$ when compared to the control levels in Exp. I.

At $36 \mathrm{hr}$, the extra $\mathrm{LH}$ release was probably due to an accumulation of readily available $\mathrm{LH}$ at the pituitary level following the initial temporary inhibition of the release. Such an increase in pituitary LH has not, however, been detected $36 \mathrm{hr}$ after treatment with TP in long-term castrated rams (unpublished data) probably because of the large pool of LH in the pituitary of these animals. No comparable extra release was observed at $120 \mathrm{hr}$, after the second inhibition phase, except in one ram treated with $25 \mu \mathrm{g} \mathrm{LH}-\mathrm{RF}$.

The most interesting finding was the decreased release of $\mathrm{LH}$ when LH-RF was given $6 \mathrm{hr}$ after the TP injection. This decrease was about $35 \%$ less than in the control rams regardless of the dose of LH-RF, a difference which was shown to be highly significant in rams treated with $100 \mu \mathrm{g}$ LH-RF when statistical analysis was possible. Under the conditions of the experiment, there was no change in the time taken to reach the peak value. If it is assumed that 
endogenous LH-RF has little or no influence on the pituitary response to exogenous LH-RF, the most plausible hypothesis is that pituitary responsiveness has been modified by a direct inhibitory action of testosterone on the hypophysial cells. This hypothesis is strongly supported by the measurement of circulating testosterone which reaches a maximum value precisely $6 \mathrm{hr}$ after the injection of TP (D. Garnier, personal communication).

In the female, modification of the pituitary response to injected LH-RF has been clearly shown to be related to the cyclic activity of the ewe (Reeves et al., 1971a, b). In the male rat, Debeljuk, Arimura \& Schally (1972) suggest that there is a direct effect of testosterone at the pituitary level, although the complete kinetics of LH release after LH-RF are not given.

The evidence presented here suggests that the first inhibition phase in the biphasic pattern of plasma LH observed in castrated rams pretreated with TP is due to a direct inhibitory action of testosterone on the LH-RF effect at the pituitary level. During the second inhibitory phase, the absence of decrease in pituitary responsiveness to LH-RF supports the hypothesis that such a decrease may be due to a temporary inhibition of the synthesis of LH-RF (Pelletier, 1970).

\section{AGKNOWLEDGMENTS}

This investigation was supported by a grant from the "Délégation Générale à la Recherche Scientifique et Technique" (No. 71.7.3019).

\section{REFERENCES}

BoLt, D. J. (1971) Changes in the concentration of luteinizing hormone in plasma of rams following administration of oestradiol, progesterone or testosterone. J. Reprod. Fert. 24, 435.

Butler, W. R., Malven, P. V., Willett, L. B. \& Bolt, D. J. (1972) Patterns of pituitary release and cranial output of LH and prolactin in ovariectomized ewes. Endocrinology, 91, 793.

Debeljuk, L., Arimura, A. \& Schally, A. V. (1972) Effect of testosterone and estradiol on the LH and FSH release induced by $\mathrm{LH}$-releasing hormone (LH-RH) in intact male rats. Endocrinology, 90, 1578.

Dierschke, D. J., Bhattacharya, A. N., Atrinson, L. E. \& Knobil, E. (1970) Girchoral oscillations of plasma LH levels in the ovariectomized rhesus monkey. Endocrinology, 87, 850.

Pelletier, J. (1970) Mode of action of testosterone propionate on the secretion and release of luteinizing hormone (LH) in the ram. Acta endocr., Copenh. 63, 290.

Pelletier, J., Kann, G., Dolais, J. \& Rosselin, G. (1968) Dosage radioimmunologique de l'hormone lutéinisante plasmatique de mouton. Mise au point de la technique de dosage. C. r. hebd. Séanc. Acad. Sci., Paris, 266, 2291.

Pelletier, J. \& Ortavant, R. (1972) Effet du propionate de testostérone sur la libération de LH chez le bélier: mise en évidence d'un double mécanisme de rétroaction. C. r. hebd. Séanc. Acad. Sci., Paris, 275, 2037.

Reeves, J. J., Arimura, A. \& Schally, A. V. (1970) Studies on dose response relationship of luteinizing hormone-releasing hormone (LH-RH) in sheep. 7. Anim. Sci. 31, 933.

Reeves, J. J., Arimura, A. \& Schally, A. V. (1971a) Changes in pituitary responsiveness to luteinizing hormone-releasing hormone (LH-RH) in anestrous ewes pretreated with estradiol benzoate. Biol. Reprod. 4, 88.

Reeves, J. J., Arimura, A. \& Schally, A. V. (1971b) Pituitary responsiveness to purified luteinizing hormone-releasing hormone (LH-RH) at various stages of the estrous cycle in sheep. J. Anim. Sci. 32, 123. 